\title{
Evaluation of released malathion and spinosad from chitosan/alginate/gelatin capsules against Culex pipiens larvae
}

This article was published in the following Dove Press journal:

Research and Reports in Tropical Medicine

19 September 2016

Number of times this article has been viewed

\section{Mohamed El Badawy' \\ Nehad EM Taktak ${ }^{2}$ \\ Osama M Awad ${ }^{2}$ \\ Souraya A Elfiki ${ }^{2}$ \\ Nadia E Abou El-Ela ${ }^{2}$ \\ 'Department of Pesticide Chemistry and Technology, Faculty of Agriculture, ${ }^{2}$ Department of Tropical Health, High Institute of Public Health, Alexandria University, Alexandria, Egypt}

\section{Video abstract}

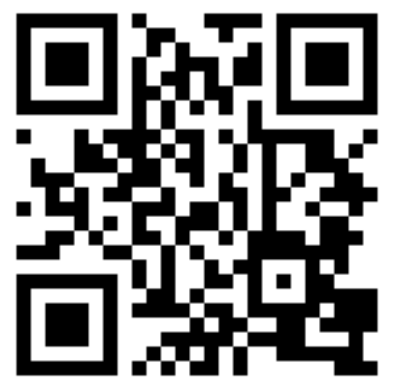

Point your SmartPhone at the code above. If you have a QR code reader the video abstract will appear. Or use: http://youtu.be/kMJ)(88) $\mathrm{Ns} 9 \mathrm{U}$

Correspondence: Nehad EM Taktak Department of Tropical Health, High Institute of Public Health, Alexandria University, Alexandria 2156I, Egypt $\mathrm{Tel}+2039575269$

Fax +2035972780

Email nehadebrahim34@yahoo.com

\begin{abstract}
Efficacy of spinosad and malathion loaded in eco-friendly biodegradable formulations was evaluated for controlling Culex pipiens larvae. Malathion (organophosphorus larvicide) and spinosad (naturally derived insecticide) were loaded on chitosan/alginate/gelatin capsules. Capsules were characterized by size measurement, scanning electron microscopy, Fourier transform infrared spectroscopy, and water uptake. In vitro release kinetics of the larvicides was studied in the running and stagnant water. Biochemical studies on the larvae treated with technical and formulated insecticides were also demonstrated. The results indicated that the released spinosad was active for a long time up to 48 and 211 days in the running and stagnant water, respectively. However, the capsules loaded with malathion showed larvicidal activity for 20 and 27 days in the running and stagnant water, respectively. Technical and formulated malathion and spinosad had an inhibition effect on acetylcholinesterase, carboxylesterase, and glutathione $S$-transferase. The results proved that the prepared capsules consisting of biodegradable polymers containing larvicides could be effective as controlled-release formulation against C. pipiens larvae for a long period.
\end{abstract}

Keywords: chitosan capsules, larvicide, controlled-release formulation, swelling, mosquitocidal activity, Culex pipiens, biochemical study

\section{Introduction}

Mosquitoes are considered to be the essential vector of many pathogens and parasites such as viruses, protozoans, bacteria, and nematodes, which cause dangerous diseases, for example, malaria, yellow fever, dengue, chikungunya fever, Zika fever, and filariasis, in tropical and subtropical areas. Culex, Aedes, and Anopheles are considered as the responsible vector of these diseases. ${ }^{1-3}$ In all the governorates of Egypt, the common house mosquito is Culex pipiens which causes infections and disability in persons. ${ }^{4}$ It is the main vector of Bancroftian filariasis (infects $\sim 120$ million persons per year, leaving several disabled), ${ }^{5}$ Rift Valley fever, and diseases caused by other viruses.$^{6-8}$

Mosquito control represents an important strategy for prevention of disease transmission and epidemic outbreaks. Insecticides commercially used for mosquito control belong to four major chemical groups including chlorinated hydrocarbons, organophosphorus, carbamates, and pyrethroids, according to the World Health Organization Pesticide Evaluation Scheme and the Egyptian Ministry of Health. ${ }^{9}$ Synthetic insecticides are most commonly used in mosquito control programs. ${ }^{10}$ However, extensive use of an 
insecticide for generations increases the risk of mosquitoes developing resistance accompanied by dangerous effects on human, nontarget organism, and the environment. ${ }^{1,11-14}$ Organophosphates are insecticides which accumulate at low levels in the environment and are hydrolyzed at high or low $\mathrm{pH} .{ }^{15,16}$ These were first developed as nerve gases, and their insecticidal effectiveness was discovered shortly thereafter. ${ }^{16,17}$ They have become widely used as replacements for organochlorine insecticides because they do not persist in organism tissues or the environment. ${ }^{16,18}$ Malathion is the most widely used within this group and was used as the main insecticide for vectors control until pyrethroids were introduced to the country between 1995 and 1997. ${ }^{19}$

Spinosad can be described as a macrocyclic lactone containing a unique tetracyclic ring to which two different sugars are attached. It consists of isomers $\mathrm{A}$ and $\mathrm{D}$ of spinosyn and is a naturally occurring product of an aerobic fermentation by Saccharopolyspora spinosa. ${ }^{20-22}$ Spinosad is also a highly effective bioinsecticide against all mosquito larval species tested thus far such as Aedes aegypti, Anopheles stephensi, and C. pipiens. ${ }^{23}$ It causes stomach and contact toxicity and degrades in the environment rapidly ${ }^{24}$ and has an excellent toxicological profile for human and environment. ${ }^{4,23,25-27}$ So, the Environmental Protection Agency has recorded spinosad as a low-risk material. ${ }^{28}$

Extensive use of insecticides in integrated control programs causes hazards to both humans and the environment. ${ }^{29,30}$ In addition, as much as $90 \%$ of the used conventional pesticides are lost or degraded, which not only increases the cost but also increases the environmental risks. ${ }^{30-32}$ The failure of the synthetic insecticides to control the insects and growing public concern for safe food and a healthy environment have encouraged the search for more environmentally benign vector control ways such as controlled-release formulations (CRFs) ${ }^{33,34} \mathrm{CRFs}$ of pesticides can remarkably reduce the consumption of pesticides and their effect on the environment. They can prolong the pesticide's activity, reduce the loss of pesticide by leaching, evaporation, and degradation, and minimize the danger of percutaneous poisoning. ${ }^{30,35,36}$ Usually, CRFs of insecticides are preferably prepared using biopolymer materials such as alginate, carboxymethyl cellulose, agarose, starch, and chitosan due to their low cost, good biological activity, free availability, nontoxicity to mammals, and high biodegradability. ${ }^{35,37,38}$

Among these materials, chitosan, a deacetylated derivative of chitin ( $N$-acetyl-d-glucosamine), is a naturally occurring polysaccharide and found abundantly in marine crustaceans, exoskeletons, and fungal cell walls. Chitosan is a cationic, biocompatible (in animal tissues), nontoxic, odorless, and biodegradable polymer having many applications in different fields. ${ }^{39-43}$ Alginate gels are widely used as matrices for CRFs in agricultural applications due to their biodegradability and the ease of incorporation of pesticides using an aqueous system at ambient temperatures. However, alginate has inherent drawbacks, such as low mechanical strength, uncontrolled degradation, and extensive water uptake properties which can result in uncontrolled and unpredicted release rates of the active pesticides. ${ }^{44-46}$ The leaching of pesticides during the preparation of alginate beads has been improved by synthesizing bi-polymeric beads of alginate with other natural polysaccharides. ${ }^{36,47-50}$

Therefore, the current study aimed to prepare eco-friendly capsules based on chitosan, alginate, and gelatin loaded with malathion and spinosad as a promising formulation against C. pipiens larvae. The capsule characterization including scanning electron microscopy (SEM), Fourier transform infrared (FT-IR) spectroscopy, physical properties, and swelling capacities is demonstrated in detail. In addition, the in vivo effects of both insecticides on biochemical parameters such as acetylcholinesterase (AChE), carboxylesterase (CaE), and glutathione $S$-transferase (GST) were also examined.

\section{Materials and methods Materials and reagents}

Low-molecular weight acid-soluble chitosan $\left(3.60 \times 10^{5} \mathrm{Da}\right.$ and $89 \%$ degree of deacetylation), sodium alginate, gelatin (type A, from porcine skin, 300 bloom), glutaraldehyde (25\%), bovine serum albumin, acetylthiocholine iodide (ATChI), 1-chloro-2,4-dinitrobenzene, 5,5'-dithiobis (2-nitrobenzoic acid), 4-nitrophenyl acetate (NPA), 1-glutathione (GSH), and ethylenediaminetetraacetic acid (EDTA) were purchased from Sigma-Aldrich Co. (St Louis, MO, USA). Technical malathion 90\%, diethyl 2-(dimethoxyphosphorothioyl) sulfanyl butanedioate, and formulated form $\left(57 \%\right.$ EC, Malasion $\left.{ }^{\circledR}\right)$ were obtained from Kafr El Zayat Pesticides \& Chemicals Co. (Gharbia, Egypt). Technical-grade spinosad $(95 \%)$ and formulated form $\left(25 \% \mathrm{G}\right.$, Spintor $\left.{ }^{\circledR}\right)$ were purchased from the Dow Chemical Company (Midland, MI, USA). All other reagents and solvents were of analytical grade and used as received.

\section{Test insect and rearing}

The $C$. pipiens larvae were obtained from susceptible reared strain provided by the Research Institute of Medical Entomology (Ministry of Health, Dokki, Gizva, Egypt) and reared under insectary conditions. Approximately, 400-600 
C. pipiens larvae were reared in white enameled and shallow dishes containing 2-3 L of dechlorinated water. These trays were covered with mesh screen to prevent oviposition by escaped adult mosquitoes and were maintained at a room temperature $\left(26^{\circ} \mathrm{C} \pm 2^{\circ} \mathrm{C}\right)$ and relative humidity $(70 \% \pm 5 \%)$ with a 14-hour:10-hour (light:dark) photoperiod. The larvae were daily fed on biscuits and yeast power in the ratio of $3: 1$ until pupation. The pupae were transported from the dishes to plastic cups containing dechlorinated water and were maintained in netting cages with wood frames $(30 \times 30 \times 30 \mathrm{~cm})$ until adults emerged. Adults were provided with $10 \%$ solution of sucrose, and females were fed on pigeon blood four times a week. ${ }^{51}$

\section{Dose-response larval bioassay of malathion and spinosad}

The toxicity of technical and formulated malathion and spinosad was evaluated at different concentrations (0.25-10 and $0.0005-0.20 \mathrm{mg} / \mathrm{L}$ for malathion and spinosad, respectively) in dechlorinated tap water. The test cups were kept at $25^{\circ} \mathrm{C} \pm 2^{\circ} \mathrm{C}$ and preferably under a photoperiod of 12 hours: 12 hours (light:dark). Larval mortality was recorded after 24 and 48 hours of the exposure. The log dose-response curves were used for the determination of the lethal concentration causing 50\% mortality $\left(\mathrm{LC}_{50}\right)$ values according to the probit analysis. ${ }^{52}$ If the control mortality was between $5 \%$ and $20 \%$, the mortalities of treated groups were corrected according to Abbott's formula. ${ }^{53}$

\section{Preparation of capsules loaded with malathion and spinosad}

Chitosan/alginate/gelatin capsules were prepared by cross-linking with glutaraldehyde according to the technique previously described by Badawy et al. ${ }^{54}$ The best type of capsules from previous study (chitosan:alginate:gelatin:gluta raldehyde $=0.25 \%: 0.5 \%: 0.625 \%: 1 \%$ ) was selected for loading the two tested technical-grade larvicides malathion and spinosad. These capsules were characterized by less swelling ratio, less diameter, spherical shape, and highest number per gram, which will give higher controlled release. The capsules were prepared following the same method mentioned earlier, in addition to mixing each insecticide (dissolved in acetonitrile) with $1 \%$ chitosan solution (w/v) and then pipetting to the alginate with glutaraldehyde solution. ${ }^{54}$

\section{Capsules characterization}

\section{Size measurement}

The size of ten replicates of dried capsule formulations was measured using LCD Digital Vernier Caliper/Micrometer
(6 inch) Gauge 150 mm (Jingkewang Technology Co., Ltd, Shenzhen, People's Republic of China) with an accuracy of $\pm 0.02 \mathrm{~mm} / 0.001 \mathrm{inch}$.

\section{Surface morphology}

SEM analysis was done using a JEOL JSM-5300 microscope (JEOL, Tokyo, Japan) to examine the capsules' surface morphology. The observations were performed at an accelerating voltage of $25 \mathrm{kV}$. The dried capsules were sputtered with gold, mounted on metal stubs with double-sided tape, and examined under a scanning electron microscope. The cross-sections of the dried capsules were also scanned.

\section{FT-IR spectroscopy}

To study the functional groups of loaded and unloaded capsules and their components, the capsules were analyzed by FT-IR spectroscopy with $\mathrm{KBr}$ discs in the range of $4,000-400 \mathrm{~cm}^{-1}$ with a resolution of $4.0 \mathrm{~cm}^{-1}$ on a Perkin Elmer FT-IR Spectrophotometer (PerkinElmer Inc., Waltham, MA, USA).

\section{Swelling properties}

The swelling capacity of the loaded and unloaded capsules was demonstrated by the following method. The water uptake ability of capsules was estimated by immersing certain weight of dried capsules $(0.05 \mathrm{~g})$ into water and then by recording the water gain at different periods up to 10 days. Excess surface water was removed by drying with soft paper, and the swelling percentage was calculated by the following equation:

$$
\text { Swelling }(\%)=\left[\frac{\left(\mathrm{W}_{\mathrm{t}}-\mathrm{W}_{\mathrm{o}}\right)}{\mathrm{W}_{\mathrm{o}}}\right] \times 100
$$

where $\mathrm{W}_{\mathrm{t}}$ and $\mathrm{W}_{\mathrm{o}}$ are the weights of swollen sample at time (t) and that of the original sample, respectively. Experiments were conducted in triplicate, and the obtained data were averaged.

\section{Spectral analysis and estimation of malathion and spinosad content in controlled-release capsules}

Absorption scan was performed in the range of 190-340 nm on $50 \mathrm{mg} / \mathrm{L}$ malathion and $25 \mathrm{mg} / \mathrm{L}$ spinosad in acetonitrile using UV/visible spectrophotometer (Alpha-1502; Laxco Inc, Bothell, WA, USA). Solvent was used as blank. The maximum wavelength appeared at 200 and $203 \mathrm{~nm}$ for spinosad and malathion, respectively. Therefore, all absorbance measurements were recorded at these wavelengths. For estimation of the 
malathion and spinosad content in capsules, a weight of $0.02 \mathrm{~g}$ of capsules was immersed in acetonitrile $(5 \mathrm{~mL})$ and grinded to disintegrate the capsules. The vial was left under room condition for 2 hours and then purified by Whatman filter paper no. 1 . The filtrate of acetonitrile was used for UV analysis at a $\lambda_{\max }$ of $200 \mathrm{~nm}$ for spinosad and $203 \mathrm{~nm}$ for malathion. The concentration of each insecticide in the product was estimated from the calibration curve. Calibration curves were obtained by using different concentrations of each insecticide (5-100 mg/L).

\section{In vitro release study in stagnant and running water}

Four weights of capsules $(0.005,0.01,0.02$, and $0.05 \mathrm{~g}$ ) were immersed in distilled water $(100 \mathrm{~mL})$ and stored at $25^{\circ} \mathrm{C} \pm 2{ }^{\circ} \mathrm{C}$. An aliquot of each sample was daily taken from each bottle at different periods and analyzed by UV spectroscopy at 200 and $203 \mathrm{~nm}$ until spinosad and malathion, respectively, became undetectable. The distilled water sample was used as a blank. The measured water samples were poured back into the dissolution cell to keep the volume constant. This technique was done for both stagnant and running water. In the running water technique, the water was removed and daily discharged. However, in the stagnant water technique, the measured water samples were poured back into the cups to keep the volume constant.

\section{Larvicidal activity of controlled-release capsules loaded with malathion and spinosad}

Larvicidal activity of malathion and spinosad released from prepared capsules against $C$. pipiens larvae was assayed using two techniques. First, bioassay in stagnant water was conducted as follows: Capsules $(0.005,0.01,0.02$, and $0.05 \mathrm{~g}$ ) were placed in $100 \mathrm{~mL}$ of water containing ten $C$. pipiens larvae, and their death was monitored as a function of time daily for a period without change of water but with fresh larvae..$^{5,56}$ The experiments were demonstrated in three replicates, and a control sample was obtained by keeping larvae in water under the same conditions but with unloaded beads. Second, the bioassay was performed in running water where the solution and larvae were discharged daily without capsules. Then, the water was replenished, fresh larvae were added, and a new death/survival count was carried out daily. The trial was repeated until a negligible mortality was obtained. The mortality was recorded in two experiments.

\section{Biochemical studies}

Specific activities of AChEs, CaEs, and GSTs were estimated in surviving larvae after 1 day of exposure to $\mathrm{LC}_{50}$ of malathion and spinosad. Larvae were homogenized by a glass/Teflon homogenizer in $40 \mathrm{mM}$ sodium phosphate buffer ( $\mathrm{pH} 7.4), 10 \mathrm{mM} \mathrm{NaCl}(1 \%, \mathrm{w} / \mathrm{v})$, and Triton X-100 at $4^{\circ} \mathrm{C}$. The homogenate was filtered through cheesecloth followed by centrifugation at 5,000 rpm (20 minutes) at $4{ }^{\circ} \mathrm{C}$. The supernatant was used immediately for assaying AChEs, CaEs, and GSTs. All the experiments were performed in triplicate. Crude protein was determined using bovine serum albumin for standard curve ${ }^{57} \mathrm{AChE}$ activity was estimated using $0.075 \mathrm{MATChI}$ as a substrate in colorimetric method. ${ }^{58}$ The assay medium $(1.5 \mathrm{~mL}$ total $)$ consisted of $10 \mu \mathrm{L}$ of $0.075 \mathrm{M}$ ATChI, $20 \mu \mathrm{L}$ of the crude enzyme, $50 \mu \mathrm{L}$ of $0.01 \mathrm{M} 5,5^{\prime}$-dithiobis(2-nitrobenzoic acid), and 1,420 $\mu \mathrm{L}$ phosphate buffer ( $\mathrm{pH} 8$ ). After a 10-minute incubation at $37^{\circ} \mathrm{C}$, the reaction was monitored at $412 \mathrm{~nm}$ by using UV/ visible spectrophotometer (Alpha-1502; Laxco Inc). The specific activity was expressed as $\Delta \mathrm{OD}_{412} \mathrm{~min}^{-1} \times \mathrm{mg}$ protein ${ }^{-1}$. CaEs activity was assayed by spectrophotometer using the substrate NPA. ${ }^{59}$ The assay medium consisted of $1,925 \mu \mathrm{L}$ of $20 \mathrm{mM}$ Tris-HCl buffer ( $\mathrm{pH}$ 8.0) containing $1 \mathrm{mM}$ (EDTA), $50 \mu \mathrm{L}$ of enzyme extract, and $25 \mu \mathrm{L}$ of $5 \mathrm{mM}$ NPA. In this method, after incubation ( 5 minutes) at $25^{\circ} \mathrm{C}$, the formation of yellow 4-nitrophenol was recorded at $405 \mathrm{~nm}$. The specific activity was expressed as $\Delta \mathrm{OD}_{405} \mathrm{~min}^{-1} \times \mathrm{mg}$ protein ${ }^{-1}$. GSTs activity was estimated by mixing $1,650 \mu \mathrm{L}$ of $100 \mathrm{mM}$ phosphate buffer ( $\mathrm{pH} 7.4$ ) containing $1 \mathrm{mM}$ EDTA, $200 \mu \mathrm{L}$ of $2.5 \mathrm{mM} \mathrm{GSH}, 50 \mu \mathrm{L}$ of enzyme extract, and $100 \mu \mathrm{L}$ of $1 \mathrm{mM}$ 1-chloro-2,4-dinitrobenzene as a substrate. ${ }^{60}$ The absorbance was recorded at $340 \mathrm{~nm}$. One unit of the activity corresponded to the quantity of enzyme conjugating $1 \mathrm{mmol}$ of GSH per minute. The specific activity was expressed as $\Delta \mathrm{OD}_{340} \mathrm{~min}^{-1} \times \mathrm{mg}$ protein ${ }^{-1}$. Blanks (same as previous experiments without crude enzyme sample) were periodically measured for nonenzymatic activities; however, no significant activity was observed for all enzymes.

\section{Statistical analysis}

Statistical analysis was performed using the SPSS software, version 21.0 (IBM Corporation, Armonk, NY, USA). Mortality percentages were recorded for all treatment bioassays and corrected using Abott's equation. ${ }^{53,61}$ Mean values and standard error were determined using three independent replications performed for each treatment. The $\mathrm{LC}_{50}$ value for the insect bioassay was recorded using log dose-response curves according to probit analysis. ${ }^{52}$ The least-square regression analysis was used for measuring $95 \%$ confidence limits. Data were analyzed by analysis of variance, and mean values were separated $(P \leq 0.05)$ using Student-Newman-Keuls test. 


\section{Results and discussion \\ Preparation of capsules loaded with malathion and spinosad}

The reaction between chitosan $(0.25 \%)$, sodium alginate $(0.5 \%)$ cross-linked with glutaraldehyde $(1 \%)$, and gelatin $(0.625 \%)$ was achieved to produce spherical capsules loaded with $16.05 \%$ malathion and $18.85 \%$ spinosad which were analyzed by UV spectrophotometer at a $\lambda_{\max }$ of 203 and $200 \mathrm{~nm}$, respectively (Table 1). Capsules were yellowish brown in color before drying and brown in color after drying. The properties of loaded and unloaded capsules are shown in Table 1. It was noted that the unloaded capsules were having higher diameter $(1,004 \mu \mathrm{m})$ than the capsules loaded with malathion $(932 \mu \mathrm{m})$, and hence, there were 820 and 2,170 capsules per gram, respectively. Likewise, spinosad-loaded capsules were $771 \mu \mathrm{m}$ in diameter, and hence, there were 3,240 capsules per gram.

In this work, it was necessary to modify chitosan structure with alginate and to cross-link with glutaraldehyde as it has been proved that the mechanical strength of chitosan capsules is low, which limits its use as a CRF. ${ }^{62,63}$ Chitosan and alginate react via ionic interaction between the carboxyl residues of alginate and the amino terminals of chitosan. ${ }^{64}$ The interaction could also be via intermolecular hydrogen bonding. ${ }^{65}$ This complexation reduces the leakage of the encapsulated substances, and decreases the porosity of the alginate capsules. Similarly, Suave et a ${ }^{66}$ loaded the malathion in microspheres of pure polymers (3-hydroxybutyrate and poly-e-caprolactone) to evaluate its performance as a CRF.

Our results are in agreement with Yan et $\mathrm{al}^{35}$ who prepared alginate-chitosan-bentonite beads loaded with pesticides as a CRF and characterized them by FT-IR spectroscopy, SEM, thermogravimetry, water uptake tests, and release studies. Singh et $a^{167}$ studied thiram fungicide's dynamics of release from starch-alginate beads to control environmental pollution. In addition, Işiklan loaded insecticide carbaryl in sodium alginate, sodium alginate/gelatin, and sodium alginate/sodium carboxymethyl cellulose beads by cross-linking with glutaraldehyde and characterized them by FT-IR spectroscopy and SEM ${ }^{68}$ The author found that the preparation conditions, such as carbaryl/sodium alginate ratio, time of exposure to glutaraldehyde, blend ratio, and temperature of release medium, impacted significantly on the release of the insecticide. Likewise, Huang et a ${ }^{69}$ loaded spinosad into microspheres using poly lactic acid as a coating material by emulsion solvent evaporation method. These microspheres were observed by SEM. The results proved that the microspheres were round beads with relatively smooth surfaces.

\section{Swelling properties}

The swelling kinetics of loaded and unloaded capsules observed during 10 days of the experiment is summarized in Figure 1. The weight of the unloaded capsules gradually increased, and the capsules exhibited a higher water absorption rate than both the loaded capsules for the first 6 days. After 24 hours, the unloaded capsules swelled rapidly. The highest degree of swelling was observed on the day $3(170 \%)$, but the swelling reduced to $80 \%$ on day 7 , and then remained constant until day 10 . However, it was noted that the swelling kinetics of the capsules loaded with malathion and spinosad tended to be more stable along the experiment $(70 \%-85 \%$ for malathion and $96 \%$ for spinosad).

Since sodium alginate and chitosan have a large number of hydrophilic groups, they are capable of extensive water uptake, so the capsules rapidly swelled at the first 3 days because of their hydrophilic contents. Later, they swelled slowly and continued to swell until they ruptured. All the capsules showed $>70 \%$ of swelling instantly within the day 1 , and later, the swelling became slow. This proved that only water might have transported within the porous polymer matrix.

Table I Properties of loaded and unloaded capsules

\begin{tabular}{llll}
\hline Parameters & Unloaded capsules & $\begin{array}{l}\text { Capsules loaded } \\
\text { with malathion }\end{array}$ & $\begin{array}{l}\text { Capsules loaded } \\
\text { with spinosad }\end{array}$ \\
\hline Components ratio (Ch:Alg:Gel:Glut:larvicide) & $0.25: 0.5: 0.625: 1.0: 0.0$ & $0.25: 0.5: 0.625: 1.0: 16.05$ & $0.25: 0.5: 0.625: 1: 18.85$ \\
Capsule color & Yellow & Brown & Brown \\
Weight before drying $(g)$ & 17.68 & 8.37 & 7.50 \\
Weight after drying $(g)$ & 1.53 & 0.68 & 0.61 \\
Capsule no/g & 820 & 2,170 & 3,240 \\
Diameter \pm SE $(\mu \mathrm{m})$ & $1,004 \pm 32$ & $931.82 \pm 24.46$ & $770.91 \pm 15.85$ \\
Flexibility before drying & Flexible & Flexible & Flexible \\
Flexibility after drying & Hard & Hard & Hard \\
\hline
\end{tabular}

Abbreviations: $\mathrm{Ch}$, chitosan; Alg, alginate; Gel, gelatin; Glut, glutaraldehyde; SE, standard error. 


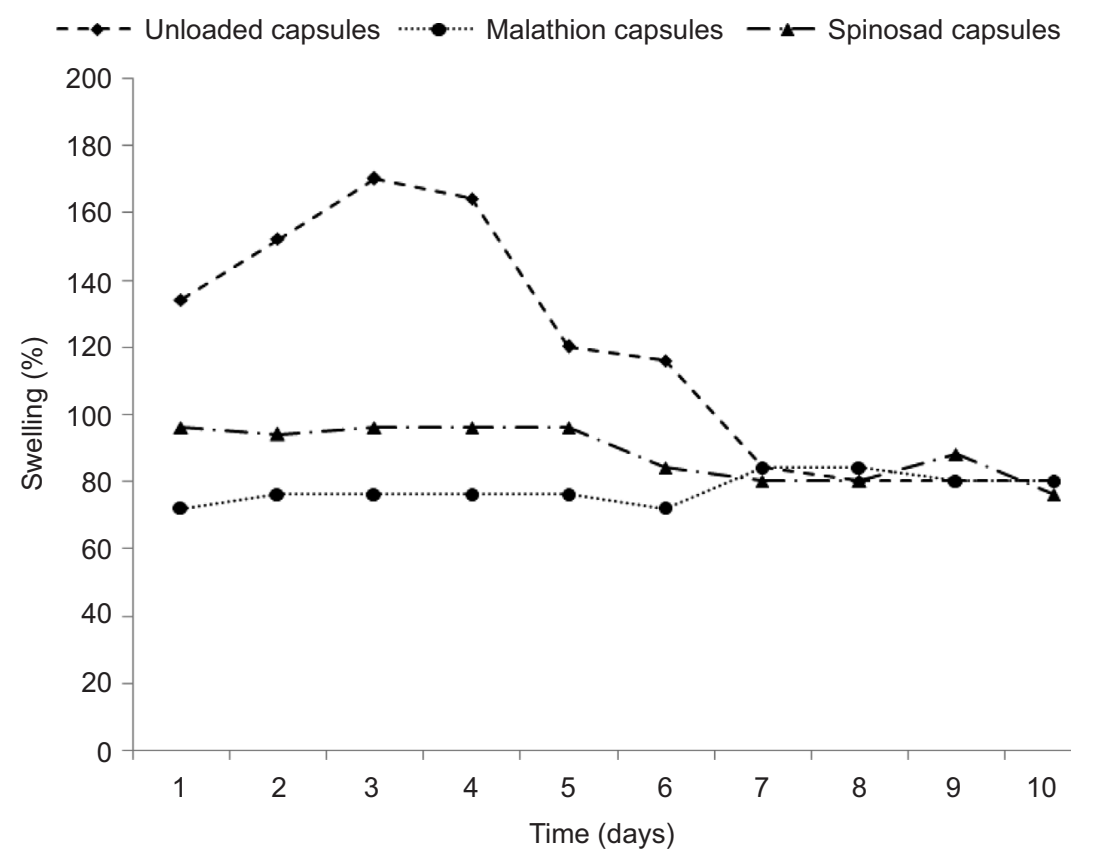

Figure I Swelling kinetics of loaded and unloaded capsules during 10 days.

Our results are in agreement with those obtained by Agnihotri and Aminabhavi ${ }^{39}$ who prepared chitosan microparticles loaded with clozapine and found that the particles swelled to a maximum of $180 \%$ of their dry mass. All the particles showed $>50 \%$ swelling immediately within the first minute, and later, the swelling became slow.

The swelling property of capsule is an effective factor that controls the release of active ingredient into the water for a long period. Swelling occurs due to the hydrophilic groups, and more positively charged amino groups along the biopolymer chain are responsible for an expanding polymer network. ${ }^{70,71}$ In addition, the swelling behavior of the capsules mainly results from the electrostatic discord between the negatively charged carboxyl groups on alginate and gelatin. Paula et al $^{56}$ prepared chitosan/cashew gum $(\mathrm{CH} / \mathrm{CG})$ beads loaded with insecticide dichlorvos. They confirmed that the unloaded and loaded beads did not differ significantly in their swelling characteristics. However, in this study, we proved that the unloaded capsules recorded high swelling degree than the loaded capsules. This result may be referring to the complexation between the polymers, which decreases the capsules porosity and the sorption of the water into capsules.

\section{SEM analysis}

The capsules initially were studied under a light stereo microscope before and after (Figure 2, CPB and CPA, respectively) drying to distinguish their characteristics. They appeared spherical in shape and yellowish gold in color before drying and turned to brown after drying. The general shape and surface morphology of the loaded and unloaded capsules were evaluated by SEM (Figure 2). The unloaded capsules were found to be irregular in shape with a longitudinal cavity (Figure 2, CPU), and their surface morphology was examined under a power of magnification of $\times 35,000$ and appeared with a lot of pores and wrinkles (Figure 2, CPUф). After loading with malathion, the capsules appeared under SEM as regular and oval shaped with a lot of wrinkles and pores (Figure 2, CPM), and their diameter ranged from 900 to $950 \mu \mathrm{m}$. However, the loading with spinosad made the capsules appear under SEM as irregularly shaped with many wrinkles, and their diameter ranged from 750 to $800 \mu \mathrm{m}$ (Figure 2, CPS). The surface morphology of malathion- and spinosad-loaded capsules under a power of magnification of $\times 35,000$ appeared more clearly with wrinkles and roughness (Figure 2, CPM $\varnothing$ and CPS $\varnothing$ ). That might have been due to the hydrophilic nature of sodium alginate and chitosan, which resulted in a high degree of dehydration after drying.

\section{FT-IR spectroscopy}

Figure 3 shows the FT-IR spectra of the unloaded capsules (Figure 3A) and capsules loaded with malathion (Figure 3B) and spinosad (Figure 3C). In all spectra, the absorption band at 3,405,3,495, and 3,407 $\mathrm{cm}^{-1}$ was recorded due to the hydroxyl group - $\mathrm{OH}$ stretching vibrations which are characteristic of natural polysaccharides. The weak absorption bands at 2,930 (Figure 3A), 2,946 (Figure 3B), and 


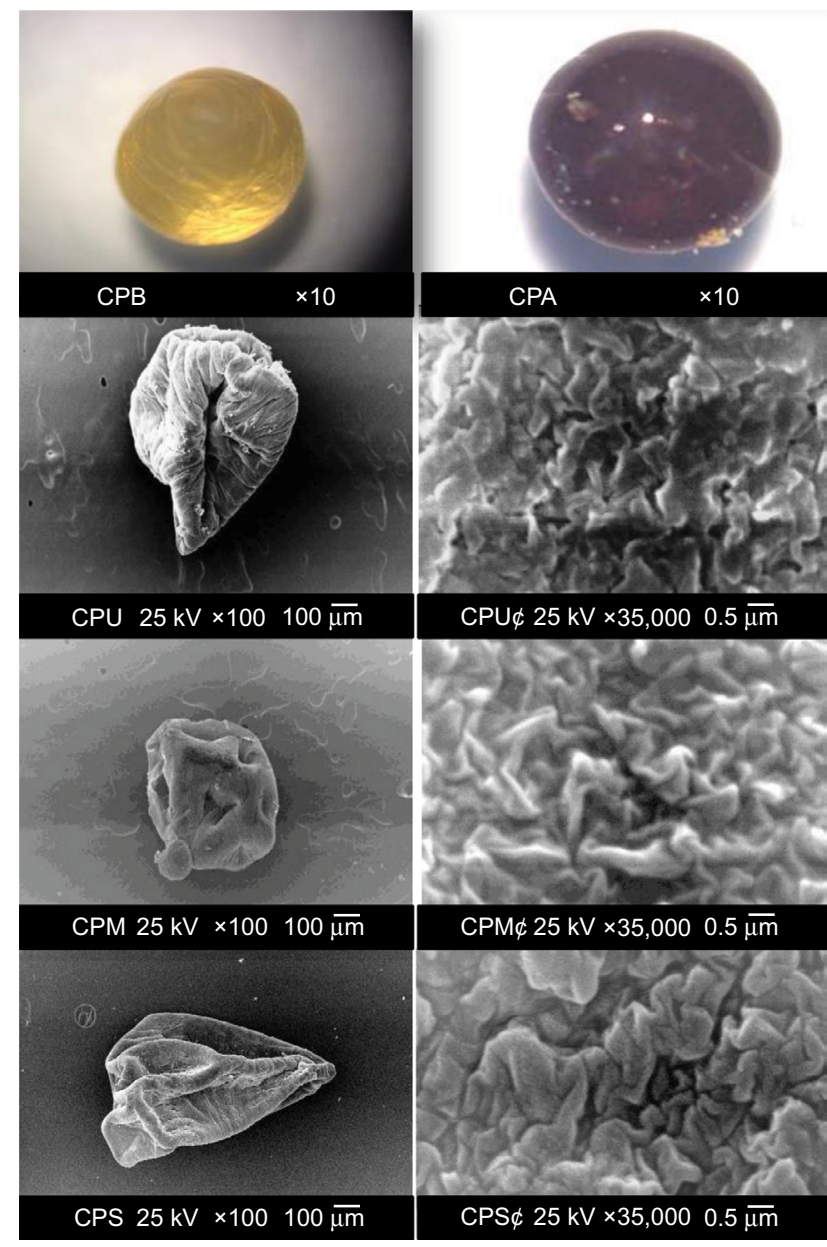

Figure 2 SEM images of loaded and unloaded capsules.

Notes: Stereo optical microscope morphology of whole shape (magnification, $\times 10)$ of the capsules prepared from chitosan (I\%), alginate (I\%), glutaraldehyde $(2 \%)$, and gelatin (2.5\%), before (CPB) and after (CPA) drying. SEM photograph of unloaded capsules $(\mathrm{CPU})$ and their surface morphology (CPU $\bar{C})$, capsules loaded with malathion (CPM) and their surface morphology (CPM $\varnothing$ ), and capsules loaded with spinosad (CPS) and their surface morphology (CPS $\phi$ ). Scale bar is $100 \mu \mathrm{m}$ and magnification is $\times 100$ for whole capsules, and scale bar is $0.5 \mu \mathrm{m}$ and magnification is $\times 35,000$ for their surface morphologies.

Abbreviation: SEM, scanning electron microscopy.

$2,925 \mathrm{~cm}^{-1}$ (Figure 3C) represented $-\mathrm{OH}$ stretching vibration. The strong asymmetric stretching absorption band at $1,649 \mathrm{~cm}^{-1}$ in spectra of unloaded and malathion-loaded capsules and that at $1,638 \mathrm{~cm}^{-1}$ in spectra of spinosad-loaded capsules were due to the presence of carboxylate anions in chitosan and sodium alginate.

In the spectrum of the malathion-loaded capsules, new strong absorption bands were noted at 1,021, 659, 1,736, and $823 \mathrm{~cm}^{-1}$. The strong stretching absorption band at $1,021 \mathrm{~cm}^{-1}$ appeared only in spectra of loaded capsules due to $\mathrm{P}=\mathrm{S}$ of malathion. The absorption band at $823 \mathrm{~cm}^{-1}$ was assigned to $\mathrm{P}-\mathrm{O}-\mathrm{C}$, and the absorption band at $1,455 \mathrm{~cm}^{-1}$ was assigned to $\mathrm{CH}_{3}$ asymmetric stretching in the malathion structure. Absorption band at $1,736 \mathrm{~cm}^{-1}$ was assigned to $\mathrm{C}=\mathrm{O}$ (esters), and the band at $659 \mathrm{~cm}^{-1}$ was assigned to alkyl groups. ${ }^{66,72,73}$
In the spectrum of the spinosad-loaded capsules, new strong absorption bands at 1,446,1,067, and $684 \mathrm{~cm}^{-1}$ were noted. The medium stretching absorption band at $1,067 \mathrm{~cm}^{-1}$ appeared only in spectra of loaded capsules due to $\mathrm{C}-\mathrm{N}$ of spinosad. The absorption band at $684 \mathrm{~cm}^{-1}$ was assigned to alkyl groups. The absorption band at $1,446 \mathrm{~cm}^{-1}$ was assigned to $\mathrm{CH}_{3}$ asymmetric stretching in the spinosad structure. ${ }^{72}$

\section{Malathion and spinosad in vitro release kinetics}

The capsules were loaded with $16.05 \%$ of malathion and analyzed by UV spectrophotometer at a $\lambda_{\max }$ of $203 \mathrm{~nm}$. A calibration curve given by the following equation: absorbance $=$ $+0.011 \mathrm{C}(\mathrm{mg} / \mathrm{L})$, with 0.980 correlation coefficient, was used for malathion determination in acetonitrile. Figure 4 shows the in vitro release of malathion $(\mathrm{mg} / 100 \mathrm{~mL}$ water) from prepared capsules in the running (Figure 4A) and stagnant water (Figure 4B) daily during 18 and 30 days, respectively. After 24 hours, in the running water, $0.05 \mathrm{~g}$ of capsules released the highest quantity of malathion $(1.074 \mathrm{mg})$ in $100 \mathrm{~mL}$ water, while $0.02,0.01$, and $0.005 \mathrm{~g}$ capsules released $0.524,0.440$, and $0.188 \mathrm{mg}$, respectively, of malathion in $100 \mathrm{~mL}$ water (Figure 4A). Then, the quantities of the malathion released from all samples $(0.005,0.01,0.02$, and $0.05 \mathrm{~g})$ significantly decreased with change of water daily. The malathion release became undetectable under UV spectroscope on days 10 and 13 for 0.005 and $0.01 \mathrm{~g}$ capsules, respectively, while with 0.02 and $0.05 \mathrm{~g}$ of capsules, malathion continued to be detected on days 15 and 17, respectively.

The kinetics of release of malathion from the capsules observed in the stagnant water experiment is summarized in Figure 4B. After 24 hours, 0.005, 0.01, 0.02, and $0.05 \mathrm{~g}$ of capsules rapidly released increased quantities of malathion $(0.159,0.402,0.794$, and $0.993 \mathrm{mg} / 100 \mathrm{~mL}$, respectively). Moreover, the accumulated release increased to the maximum values at days $7(0.652 \mathrm{mg} / 100 \mathrm{~mL}$ for $0.005 \mathrm{~g})$ and $9(1.523$, 2.628 , and $5.256 \mathrm{mg} / 100 \mathrm{~mL}$ for $0.01,0.02$, and $0.05 \mathrm{~g}$ of capsules, respectively). Then, the release decreased gradually and became undetectable at days $15,22,25$, and 30 for 0.005 , $0.01,0.02$, and $0.05 \mathrm{~g}$ of capsules, respectively.

Likewise, prepared capsules of spinosad were loaded with $18.85 \%$ technical active ingredient and were analyzed by UV spectrophotometer at a $\lambda_{\max }$ of $200 \mathrm{~nm}$. A calibration curve given by the following equation: absorbance $=$ $+0.024 \mathrm{C}(\mathrm{mg} / \mathrm{L})$, with 0.979 correlation coefficient, was used for spinosad determination in acetonitrile. Figure 5 shows the in vitro release of spinosad $(\mathrm{mg} / 100 \mathrm{~mL}$ water) from prepared capsules in the running (Figure 5A) and stagnant 
A

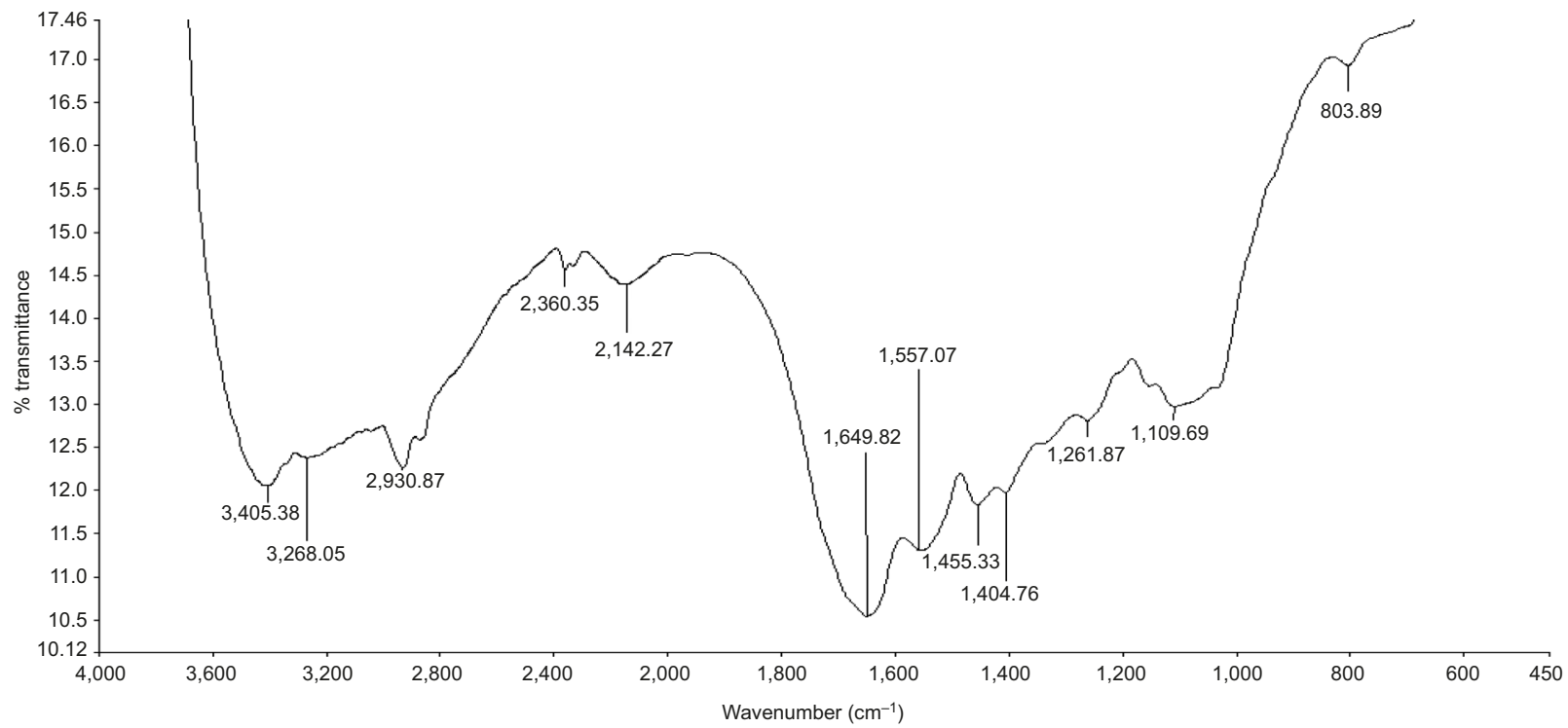

B
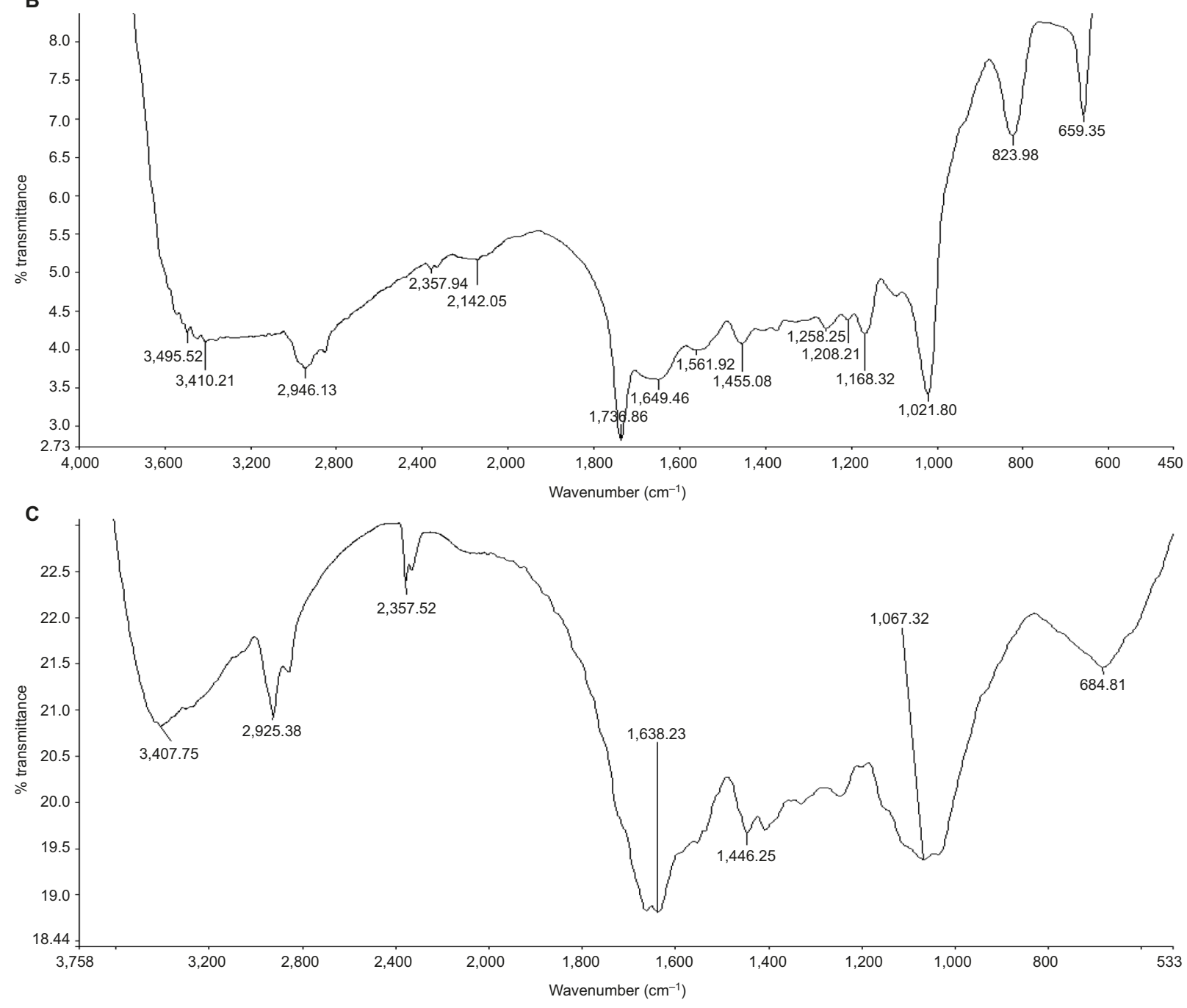

Figure 3 Fourier transform infrared spectra.

Notes: Unloaded capsules (A). Capsules loaded with malathion (B) and spinosad (C). 

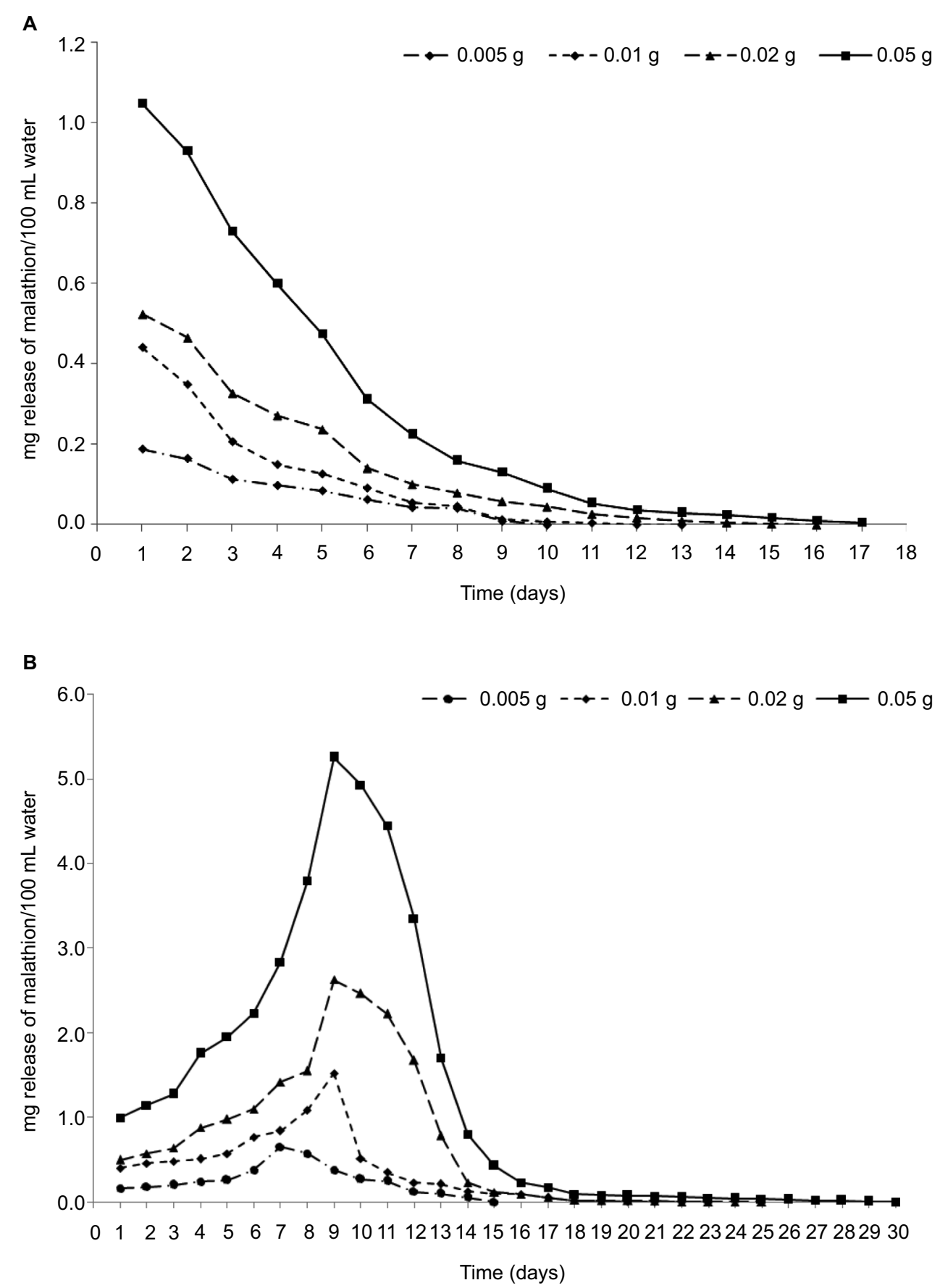

Figure $4 \mathrm{In}$ vitro release kinetics of the larvicide malathion determined by UV spectrophotometric assay.

Notes: Running water (A). Stagnant water (B).

Abbreviation: UV, ultraviolet.

water (Figure 5B) daily for 24 and 47 days, respectively. After the day 1 , the highest quantity of spinosad $(0.505 \mathrm{mg})$ released in $100 \mathrm{~mL}$ from the capsules with the highest weight $(0.05 \mathrm{~g})$ in the running water followed by $0.202,0.122$, and $0.098 \mathrm{mg} / 100 \mathrm{~mL}$ water from $0.02,0.01$, and $0.005 \mathrm{~g}$ of capsules, respectively (Figure $5 \mathrm{~A}$ ). Then, the quantities of the spinosad gradually released from all samples $(0.005$, $0.01,0.02$, and $0.05 \mathrm{~g}$ ) significantly decreased with change of water daily. The spinosad release became undetectable as determined by the UV spectroscopy on the days 12,16 , 20 , and 24 for $0.005,0.01,0.02$, and $0.05 \mathrm{~g}$ of capsules, respectively.

The kinetics of release of spinosad from the capsules observed in the stagnant water experiment is shown in Figure $5 \mathrm{~B}$. The quantities of spinosad released from the capsules $(0.005,0.01,0.02$, and $0.05 \mathrm{~g})$ rapidly increased on the day 1 $(0.103,0.144,0.212$, and $0.529 \mathrm{mg} / 100 \mathrm{~mL}$, respectively). Moreover, the release increased to maximum values at day 7 

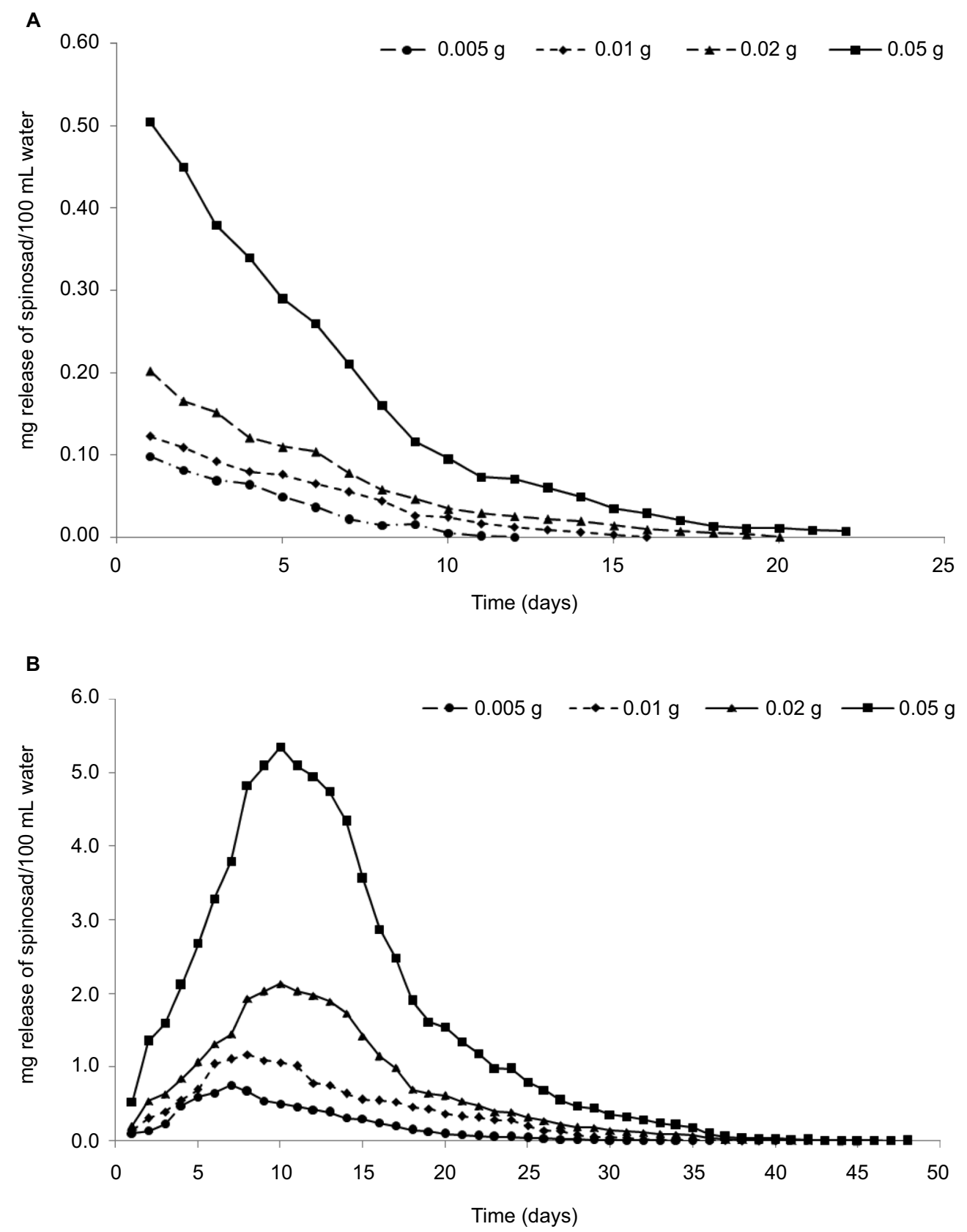

Figure $\mathbf{5}$ In vitro release kinetics of the larvicide spinosad determined by UV spectrophotometric assay.

Notes: Running water (A). Stagnant water (B).

Abbreviation: UV, ultraviolet.

$(0.756 \mathrm{mg} / 100 \mathrm{~mL})$ for $0.005 \mathrm{~g}$, day $8(1.171 \mathrm{mg} / 100 \mathrm{~mL})$ for $0.01 \mathrm{~g}$, and day $10(2.140$ and $5.394 \mathrm{mg} / 100 \mathrm{~mL})$ for 0.02 and $0.05 \mathrm{~g}$ of capsules, respectively. Then, the release decreased gradually and became undetectable at days 36, 39, 46, and 49 for $0.005,0.01,0.02$, and $0.05 \mathrm{~g}$ of capsules, respectively. It was noted that the malathion and spinosad releases were highly accumulated in stagnant water than running water. Our results were similar to those obtained by Paula et $\mathrm{al}^{56}$ who loaded chitosan and $\mathrm{CH} / \mathrm{CG}$ beads with $5.15 \%-71.4 \%$ of 2,2-dichlorovinyldimethyl phosphate and studied in vitro release behavior of this larvicide. They found that the in vitro release was similar for $\mathrm{CH}$ and $\mathrm{CH} / \mathrm{CG}$ beads, and faster release being observed after 5 hours for $\mathrm{CH} / \mathrm{CG}$ beads at an equilibrium (30 hours), such that $\mathrm{CH}$ and $\mathrm{CH} / \mathrm{CG}$ beads released up to $55 \%$ and $66 \%$ of the larvicide, respectively.

\section{Larvicidal activity of controlled-release capsules}

Larvicidal activity of controlled-release capsules loaded with malathion and spinosad against the third-instar larvae of C. pipiens according to the larval mortality percentages for different weights of capsules $(0.005,0.01,0.02$, and $0.05 \mathrm{~g})$ 
is shown in Figures 6 and 7, respectively, as observed in running water (Figures 6A and 7A) and stagnant water (Figures $6 \mathrm{~B}$ and $7 \mathrm{~B}$ ) experiments. After 24 hours, in the running and stagnant water experiments, mortality percentage was recorded as $100 \%$ for 0.05 and $0.02 \mathrm{~g}$ of capsules, and $60 \%$ and $50 \%$ for 0.01 and $0.005 \mathrm{~g}$ of capsules, respectively, for malathion product. In running water, larval mortality percentage decreased rapidly with change of water daily for all weights of capsules and reached $0 \%$ on days 11,12 , and 13 for $0.005,0.01$, and $0.02 \mathrm{~g}$ of capsules, respectively (Figure $6 \mathrm{~A})$. Quantity of malathion released from $0.05 \mathrm{~g}$ of capsules caused the larval mortality percentage to decrease to $0 \%$ on day 20. In stagnant water, the quantity of accumulated malathion released from $0.05 \mathrm{~g}$ of capsules exhibited $100 \%$ mortality up to the day 7 , and this amount exhibited larval mortality for a long period ( $50 \%$ on 15 days). Then, the larval mortality gradually decreased to $0 \%$ on days 16 and 20 for capsule weights of 0.005 and $0.01 \mathrm{~g}$, respectively. At the weights of 0.02 and $0.05 \mathrm{~g}$, the larval mortality gradually decreased from $100 \%$ to $0 \%$ on days 24 and 27 , respectively (Figure 6B).

In the case of spinosad capsules (Figure 7), in the stagnant and running water experiments, after 24 hours, larval mortality percentage was recorded as $90 \%$ for $0.005 \mathrm{~g}$ of capsules and $100 \%$ for $0.01,0.02$, and $0.05 \mathrm{~g}$ of capsules. In the running water, with change of water daily, larval mortality percentage decreased to $40 \%$ on day 25 with $0.05 \mathrm{~g}$ of capsules and then to $0 \%$ on day 48 (Figure 7A). In stagnant water, the accumulated spinosad released from $0.05 \mathrm{~g}$ of capsules exhibited $100 \%$ mortality up to 7 months. The $0.02 \mathrm{~g}$ of capsules exhibited $100 \%$ larval mortality till day 92 , and then the mortality percentage decreased gradually
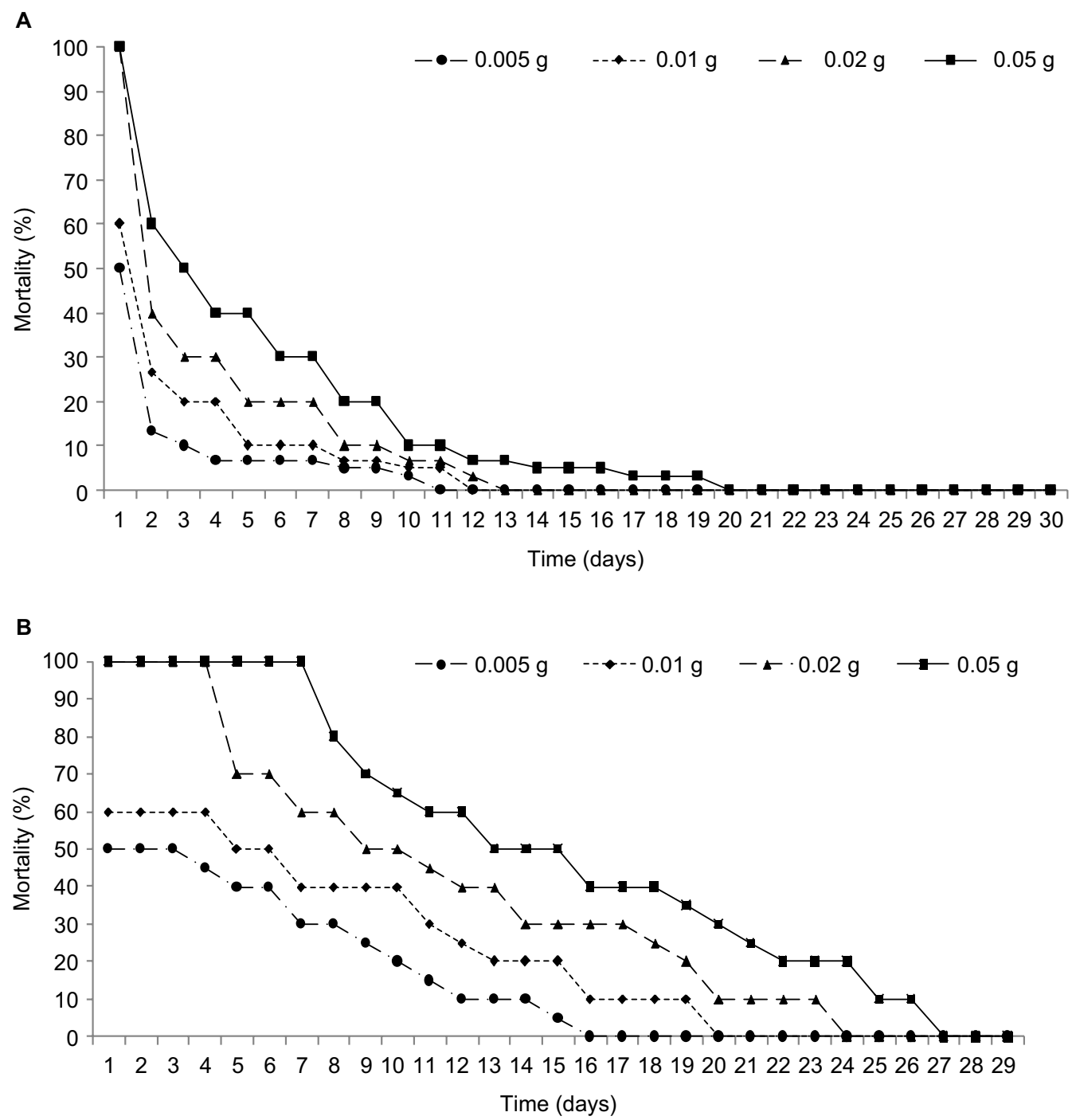

Figure 6 Larvicidal activity of controlled-release capsules according to mortality percentage for different weights of capsules (0.005, $0.01,0.02$, and 0.05 g) loaded with malathion (16.05\% calculated by UV spectroscopy) for a period of time.

Notes: Running water (exchange of larvae and water together) (A). Stagnant water (exchange of larvae only) (B).

Abbreviation: UV, ultraviolet. 

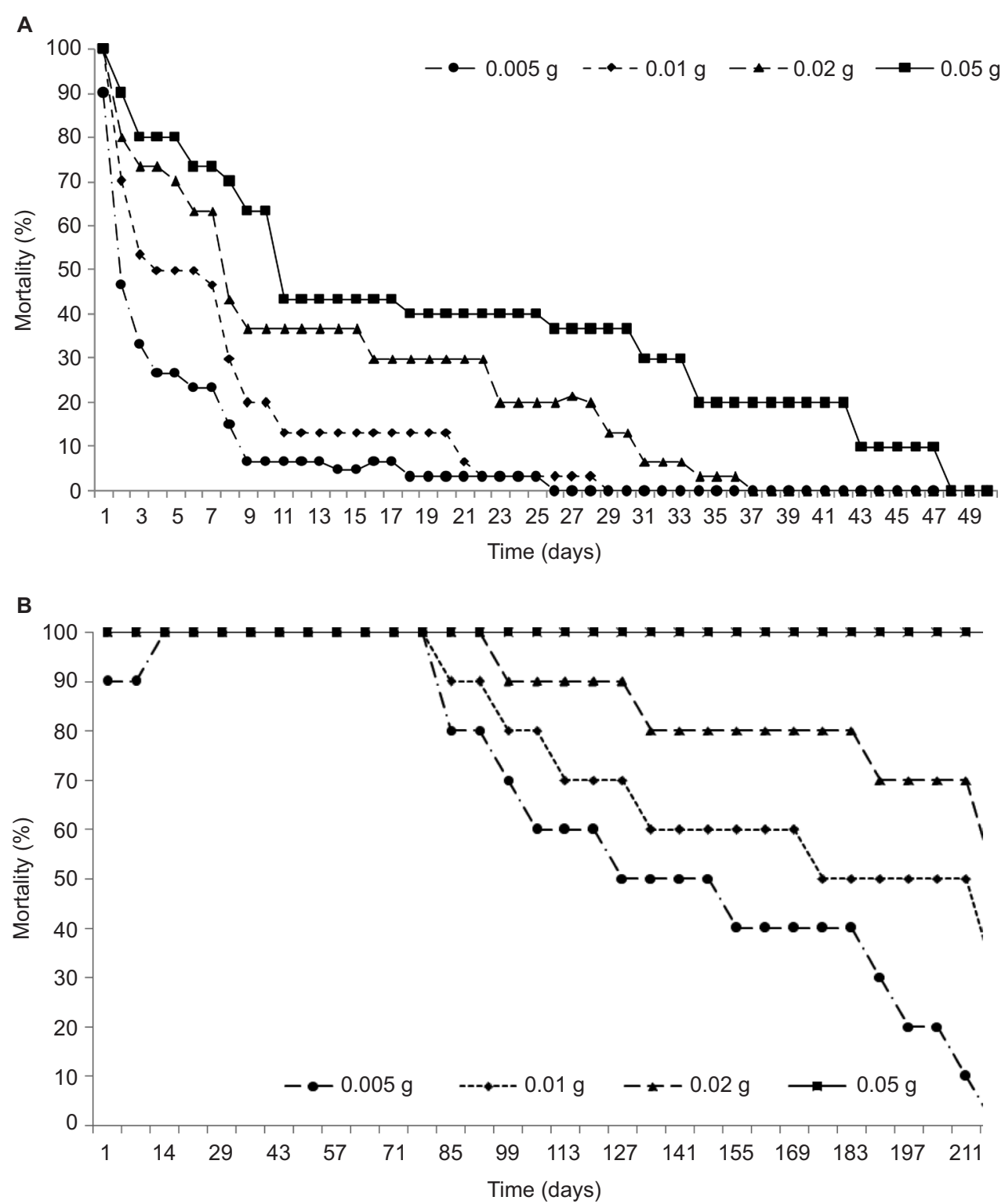

Figure 7 Larvicidal activity of controlled-release capsules according to mortality percentage for different weights of capsules ( $0.005,0.01,0.02$, and $0.05 \mathrm{~g})$ loaded with spinosad (18.85\%) calculated by UV spectroscopy for a period.

Notes: Running water (exchange of larvae and water together) (A). Stagnant water (exchange of larvae only) (B).

Abbreviation: UV, ultraviolet.

to $50 \%$ on day 218 , while the 0.01 and $0.005 \mathrm{~g}$ of capsules exhibited $30 \%$ and $0 \%$ larval mortality, respectively, on the same day (Figure 7B).

This result is in agreement with those obtained previously by Paula et $\mathrm{al}^{56}$ who reported that the dichlorvos (2,2-dichlorovinyldimethyl phosphate) loaded in $\mathrm{CH} / \mathrm{CG}$ beads resulted in the highest larval mortality of Aedes sp. with high masses of beads used. However, their data differed from ours as $\mathrm{CH} /$ CG beads showed only $50 \%$ mortality after 7 days. Mulla et $\mathrm{al}^{74}$ studied the in vivo release of Bti tablets and a zeolite granules formulation of temephos (1\%) against Ae. aegypti for 6 months. They reported that $0.37 \mathrm{~g}$ of Bti/50 L of water provided control for $\sim 90-112$ days, whereas the temephos formulations at $5 \mathrm{~g} / 50 \mathrm{~L}$ of water $(100,000 \mathrm{ppm})$ yielded $\sim 100 \%$ control for $>6$ months. On the contrary, Toma et $\mathrm{al}^{75}$ prepared a Bti tablet formulation (34,000 ppm) and reported that it induced $100 \%$ larval mortality of $A$. albopictus after 24 hours; however, the larvicidal activity lasted for only $\sim 48$ hours. Our study is also in agreement with Bhan et $\mathrm{al}^{76}$ who studied the formulation of temephos and imidacloprid based on biodegradable and biocompatible polyethylene gly$\mathrm{col}$ in different ratios. They studied this formulation against Culex quinquefasciatus and found that the temephos capsules were more toxic than the imidacloprid capsules with $\mathrm{LC}_{50}$ values of $0.013,0.010$, and $0.003 \mathrm{mg} / \mathrm{L}$ after 24,48 , and 72 hours, respectively. 


\section{Biochemical studies}

The dose-response test evaluating the efficacy of the technical insecticide malathion against $C$. pipiens showed an $\mathrm{LC}_{50}$ value of $1.108 \mathrm{mg} / \mathrm{L}$ (Table 2). These results confirmed the results obtained by Selvi et al ${ }^{77}$ who found the $\mathrm{LC}_{50}$ values at the range from 0.8763 to $1.5788 \mathrm{mg} / \mathrm{L}$ against $C$. quinquefasciatus. On the contrary, the results recorded by Zahran and Abdelgaleil ${ }^{78}$ showed that this value was $2.2 \times 10^{-3} \mathrm{mg} / \mathrm{L}$ against $C$. pipiens, and those by Rawash et $\mathrm{al}^{79}$ found that the value ranged between 0.0027 and $0.0043 \mathrm{mg} / \mathrm{L}$. However, the technical spinosad showed an $\mathrm{LC}_{50}$ value of $0.075 \mathrm{mg} / \mathrm{L}$ against $C$. pipiens (Table 2). On the contrary, the results obtained by Kovendan et $\mathrm{al}^{80}$ reported that spinosad has less effect against third-instar larvae of Ae. aegypti with an $\mathrm{LC}_{50}$ of $74.070 \mathrm{mg} / \mathrm{L}$.

To explore some biochemical actions, the effect of the $\mathrm{LC}_{50}$ values of technical and formulated malathion and spinosad on AChEs, CaEs, and GSTs isolated from C. pipiens larvae treated for 24 hours was studied. The data are recorded in Table 3 as specific activity $\left(\Delta \mathrm{OD} \mathrm{min}^{-1} \times \mathrm{mg}\right.$ protein ${ }^{-1}$ ) and as inhibition percentages for each enzyme. The untreated C. pipiens larvae had a specific activity of 5.49, 2.98, and
1.23 $\Delta \mathrm{OD} \mathrm{min}^{-1} \times \mathrm{mg}$ protein ${ }^{-1}$ for AChEs, CaEs, and GSTs, respectively. However, technical malathion reduced the specific activities to $0.34,0.00$, and $0.17 \Delta \mathrm{OD} \mathrm{min}^{-1} \times \mathrm{mg}$ protein $^{-1}$, respectively, for the same enzymes. In addition, technical spinosad reduced the specific activities to $0.69,0.53$, and $0.25 \Delta \mathrm{OD} \mathrm{\textrm {min } ^ { - 1 } \times \mathrm { mg } \text { protein }}{ }^{-1}$, respectively, for the same enzymes. It was noted that the capsules loaded with technical malathion exhibited the highest inhibition percentage in the case of CaEs (100\%) than AChEs (93.78\%) and GSTs $(86.10 \%)$. Likewise, technical spinosad exhibited the highest inhibition percentage in the case of AChEs $(87.36 \%)$ than CaEs $(82.12 \%)$ and GSTs $(79.31 \%)$. In the case of the same mosquitocidal formulations, formulated malathion reduced the specific activities to $0.7,1.17$, and $0.44 \Delta \mathrm{OD} \mathrm{min}^{-1} \times \mathrm{mg}$ protein $^{-1}$ for AChEs, CaEs, and GSTs, respectively, and exhibited the highest inhibition percentage in the case of AChEs (87.25\%) more than GSTs (64.80\%) and CaEs (60\%). Likewise, formulated spinosad reduced the specific activities to 2.8, 0.6, and $0.35 \Delta \mathrm{OD} \mathrm{min}^{-1} \times \mathrm{mg}$ protein ${ }^{-1}$ for AChEs, CaEs, and GSTs, respectively. It was clear that formulated spinosad exhibited the highest inhibition percentage in the case of CaEs (79.86\%) more than GSTs (72\%) and AChEs (48.99\%).

Table 2 Larval bioassay for technical and formulation malathion and spinosad against Culex pipiens

\begin{tabular}{|c|c|c|c|c|c|c|c|}
\hline \multirow[t]{2}{*}{ Insecticide } & \multirow[t]{2}{*}{ Time (hours) } & \multirow[t]{2}{*}{$\mathrm{LC}_{50}(\mathrm{mg} / \mathrm{L})$} & \multicolumn{2}{|c|}{$\begin{array}{l}\text { 95\% confidence limits } \\
(\mathrm{mg} / \mathrm{L})\end{array}$} & \multirow[t]{2}{*}{ Slope $^{a} \pm$ SE } & \multirow[t]{2}{*}{ Intercept $^{\mathrm{b}} \pm \mathrm{SE}$} & \multirow[t]{2}{*}{$\chi^{2 c}$} \\
\hline & & & Lower & Upper & & & \\
\hline \multirow[t]{2}{*}{ Malathion (technical) } & 24 & 1.108 & 0.508 & 2.209 & $1.403 \pm 0.111$ & $-0.063 \pm 0.058$ & 22.686 \\
\hline & 48 & 0.750 & 0.255 & 1.568 & $1.476 \pm 0.112$ & $0.184 \pm 0.059$ & 30.094 \\
\hline \multirow[t]{2}{*}{ Malathion (formulation) } & 24 & 4.407 & 4.071 & 4.760 & $4.239 \pm 0.348$ & $-2.730 \pm 0.242$ & 3.997 \\
\hline & 48 & 3.397 & 2.790 & 4.044 & $4.207 \pm 0.299$ & $-2.234 \pm 0.188$ & $13.80 \mid$ \\
\hline \multirow[t]{2}{*}{ Spinosad (technical) } & 24 & 0.075 & 0.059 & 0.102 & $2.74 I \pm 0.25 I$ & $3.080 \pm 0.3$ & 13.310 \\
\hline & 48 & 0.048 & 0.023 & 0.072 & $2.331 \pm 0.218$ & $3.084 \pm 0.275$ & 25.926 \\
\hline \multirow[t]{2}{*}{ Spinosad (formulation) } & 24 & 0.008 & 0.006 & 0.01 & $2.725 \pm 0.227$ & $5.764 \pm 0.449$ & 10.203 \\
\hline & 48 & 0.001 & 0 & 0.003 & $1.95\rfloor+0.425$ & $5.543+0.898$ & 7.727 \\
\hline
\end{tabular}

Notes: aSlope of the concentration-mortality regression line \pm SE. intercept of the regression line \pm SE. cChi-square value.

Abbreviation: $\mathrm{LC}_{50}$, lethal concentration causing $50 \%$ mortality; SE, standard error.

Table 3 Biochemical effects of technical and formulated malathion and spinosad at their LC $_{50}$ values on the AChE, CaE, and GST in Culex pipiens larvae after 24 hours of the treatment

\begin{tabular}{|c|c|c|c|c|c|c|}
\hline \multirow[t]{2}{*}{ Treatment } & \multicolumn{3}{|c|}{ Specific activity ( $\Delta O D \mathrm{~min}^{-1} \times \mathrm{mg}^{-1}$ protein $) \pm \mathrm{SE}$} & \multicolumn{3}{|c|}{ \% Inhibition } \\
\hline & AChE & $\mathrm{CaE}$ & GST & AChE & $\mathrm{CaE}$ & GST \\
\hline Control (untreated capsules) & $5.49 \pm 0.2^{\mathrm{a}}$ & $2.98 \pm 0.08^{\mathrm{a}}$ & $1.23 \pm 0.09^{\mathrm{a}}$ & 0.00 & 0.00 & 0.00 \\
\hline Technical malathion $\left(\mathrm{LC}_{50}=\mathrm{I} .108 \mathrm{mg} / \mathrm{L}\right)$ & $0.34 \pm 0.01^{d}$ & $0.00 \pm 0.00^{d}$ & $0.17 \pm 0.01^{d}$ & 93.78 & 100 & 86.10 \\
\hline Formulated malathion $\left(\mathrm{LC}_{50}=4.407 \mathrm{mg} / \mathrm{L}\right)$ & $0.7 \pm 0.02^{c}$ & $1.17 \pm 0.02^{c}$ & $0.44 \pm 0.02^{\mathrm{c}, \mathrm{d}}$ & 87.25 & 60.73 & 64.80 \\
\hline Technical spinosad $\left(\mathrm{LC}_{50}=0.075 \mathrm{mg} / \mathrm{L}\right)$ & $0.69 \pm 0.03^{c}$ & $0.53 \pm 0.06^{b}$ & $0.25 \pm 0.00^{b}$ & 87.36 & 82.12 & 79.31 \\
\hline Formulated spinosad $\left(\mathrm{LC}_{50}=0.008 \mathrm{mg} / \mathrm{L}\right)$ & $2.8 \pm 0.02^{\mathrm{b}}$ & $0.6 \pm 0.02^{c}$ & $0.35 \pm 0.02^{b, c}$ & 48.99 & 79.86 & 72.00 \\
\hline
\end{tabular}

Note: Different letters in the same column indicate statistically significant differences according to Student-Newman-Keuls test ( $P \leq 0.05)$. The values indicated by the different letters in the same columns were compared, and that showed significant difference. On the contrary, the values indicated with the same letter in the same column showed that there is no significant difference between them.

Abbreviations: AChE, acetylcholinesterase; CaE, carboxylesterase; GST, glutathione S-transferase; $\mathrm{LC}_{50}$, lethal concentration causing $50 \%$ mortality; OD, optical density; SE, standard error. 
This result proved that the malathion as an organophosphorus insecticide is a specific inhibitor of AChEs. Multiple forms of $\mathrm{AChE}$, which confer varying degrees of resistance, have been found in a variety of arthropods. ${ }^{81-83}$ Our study is in agreement with the results obtained by Chen et $\mathrm{al}^{84}$ who studied the inhibitory effect of temephos (organophosphorus insecticide) on the nonspecific esterases, mixed function oxidases, GSTs, and AChEs, and reported that the specific activities of AChEs in Ae. aegypti larvae ranged from 0.08 to $0.13 \Delta \mathrm{OD} \mathrm{min}^{-1} \times \mathrm{mg}$

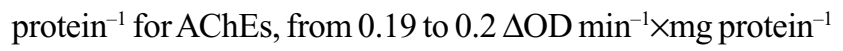
for CaEs, and from 0.07 to $0.15 \Delta \mathrm{OD} \mathrm{min}^{-1} \times \mathrm{mg}$ protein ${ }^{-1}$ for GSTs at $10 \mathrm{mg} / \mathrm{L}$ formulated temephos. Vaughan et a ${ }^{85}$ found that paraoxon (an organophosphorus insecticide) caused 90\% inhibition of AChEs in Ae. aegypti. In addition, spinosad affected unique sites on receptors for gamma-aminobutyric acid and nicotinic acetylcholine in the insect nervous system. Our study is in agreement with the results obtained by Kady et $\mathrm{al}^{4}$ who studied the toxicity of two bio-insecticides (Spinotoram $12 \%$ and Vertemic 1.8\%) compared with Methomyl (Lannete $90 \%$ SP) against laboratory strain of mosquito species $(C$. pipiens and Anopheles multicolor).

\section{Conclusion}

The biopolymer capsules based on a combination of chitosan, alginate, and gelatin were successfully prepared to envelop the insecticides malathion and spinosad for controlling their release against larvae of $C$. pipiens. Release kinetics of both the insecticides was evaluated by in vivo and in vitro assays in running and stagnant water daily for a long period. The results proved that the capsules prepared with spinosad exhibited high residual activities against the larvae for a long period than those prepared with malathion. These results, together with a simple preparation technique, indicate the applicability of these biodegradable capsules as an eco-friendly formulation as carrier for different larvicides and controlling their release.

\section{Acknowledgment}

The authors acknowledge and cordially thank the Misr El Kheir Foundation: Science, Technology and Innovation Program for supporting and funding this work under the project code LGA05130114.

\section{Disclosure}

The authors report no conflicts of interest in this work.

\section{References}

1. Barbosa S, Black WC 4th, Hastings I. Challenges in estimating insecticide selection pressures from mosquito field data. PLoS Negl Trop Dis. 2011;5(11):e1387.
2. Jang Y-S, Kim M-K, Ahn Y-J, Lee H-S. Larvicidal activity of Brazilian plants against Aedes aegypti and Culex pipiens pallens (Diptera: Culicidae). Agric Chem Biotechnol. 2002;45(3):131-134.

3. Park Y, Jung JK, Kim Y. A mixture of Bacillus thuringiensis subsp. israelensis with Xenorhabdus nematophila-cultured broth enhances toxicity against mosquitoes Aedes albopictus and Culex pipiens pallens (Diptera: Culicidae). J Econ Entomol. Epub 2016 Mar 27.

4. Kady GAE, Kamel NH, Mosleh YY, Bahght IM. Comparative toxicity of two bio-insecticides (Spinotoram and Vertemic) compared with methomyl against Culex pipiens and Anopheles multicolor. World $J$ Agric Sci. 2008;4(2):198-205.

5. Yadav S. Dose optimization of thermal fogging trials for household insecticide formulation (EC) against Aedes aegypti (L.). Curr Biotica. 2012;6(1):71-79.

6. Abdel-Hamid YM, Soliman MI, Allam KM. Spatial distribution and abundance of culicine mosquitoes in relation to the risk of filariasis transmission in El Sharqiya Governorate, Egypt. Egypt Acad J Biol Sci. 2009;1:39-48.

7. Hoogstraal H, Meegan JM, Khalil GM, Adham FK. The Rift Valley fever epizootic in Egypt 1977-1978 2. Ecological and entomological studies. Trans R Soc Trop Med Hyg. 1979;73(6):624-629.

8. Darwish M, Hoogstraal H. Arboviruses Infecting Humans and Lower Animals in Egypt: A Review of Thirty Years of Research. Egypt: Egyptian Public Health Association; 1981.

9. Becker N, Petrić D, Zgomba M, et al. Chemical control. In: Becker N, editor. Mosquitoes and Their Control. Berlin: Springer; 2010:441-475.

10. Rozendaal JA. Vector Control: Methods for Use by Individuals and Communities. Geneva: World Health Organization; 1997.

11. Joseph CC, Ndoile MM, Malima RC, Nkunya MH. Larvicidal and mosquitocidal extracts, a coumarin, isoflavonoids and pterocarpans from Neorautanenia mitis. Trans R Soc Trop Med Hyg. 2004;98(8):451-455.

12. Yang $P, M a Y$, Zheng $S$. Adulticidal activity of five essential oils against Culex pipiens quinquefasciatus. J Pestic Sci. 2005;30(2):84-89.

13. Gill HK, Garg H. Pesticide: Environmental Impacts and Management Strategies. Croatia: Pesticides-Toxic Effects Intech Rijeka; 2014:187-230.

14. Mahyoub JA, Rehman H, Saggu S, et al. Insecticide susceptibility in larval populations of the West Nile vector Culex pipiens L.(Diptera: Culicidae) in Saudi Arabia. Asian Pac J Trop Biomed. 2016;6(5):390-395.

15. Trebše P, Arčon I. Degradation of organophosphorus compounds by X-ray irradiation. Radiat Phys Chem. 2003;67(3-4):527-530.

16. Manjarres-Suarez A, Olivero-Verbel J. Chemical control of Aedes aegypti: a historical perspective. Rev Costarric Salud Pública. 2013;22(1):68-75.

17. Grue CE, Gibert PL, Seeley ME. Neurophysiological and behavioral changes in non-target wildlife exposed to organophosphate and carbamate pesticides: thermoregulation, food consumption, and reproduction. Am Zool. 1997;37(4):369-388.

18. Williams PL, James RC, Roberts SM. Principles of Toxicology: Environmental and Industrial Applications. New York: John Wiley \& Sons; 2000.

19. Karunaratne SH, Hemingway J. Malathion resistance and prevalence of the malathion carboxylesterase mechanism in populations of mosquito vectors of disease in Sri Lanka. Bull World Health Organ. 2001;79(11):1060-1064.

20. Athanassiou CG, Kavallieratos NG, Chintzoglou GJ. Effectiveness of spinosad dust against different European populations of the confused flour beetle, Tribolium confusum Jacquelin du Val. J Stored Prod Res. 2008;44(1):47-51.

21. Arthurs SP, Lacey LA, Miliczky ER. Evaluation of the codling moth granulovirus and spinosad for codling moth control and impact on non-target species in pear orchards. Biol Control. 2007;41(1):99-109.

22. Paulraj MG, Kumar PS, Ignacimuthu S, Sukumaran D. Natural insecticides from actinomycetes and other microbes for vector mosquito control. In: Vijay V, Gopalakrishnan R, editors. Herbal Insecticides, Repellents and Biomedicines: Effectiveness and Commercialization. New Delhi: Springer; 2016:85-99. 
23. Hertlein MB, Mavrotas C, Jousseaume C, et al. A review of spinosad as a natural product for larval mosquito control. J Am Mosq Control Assoc. 2010;26(1):67-87.

24. Cisneros J, Goulson D, Derwent LC, Penagos DI, Hernández O, Williams T. Toxic effects of spinosad on predatory insects. Biol Control. 2002;23(2):156-163.

25. Romi R, Proietti S, Di Luca M, Cristofaro M. Laboratory evaluation of the bioinsecticide spinosad for mosquito control. J Am Mosq Control Assoc. 2006;22(1):93-96.

26. Bahgat IM, El Kady GA, Temerak SA, Lysandrou M. The natural bioinsecticide spinosad and its toxicity to combat some mosquito species in Ismailia Governorate, Egypt. World J Agric Sci. 2007;3(4):396-400.

27. Williams T, Valle J, Viñuela E. Is the naturally derived insecticide Spinosad $^{\circledR}$ compatible with insect natural enemies? Biocontrol Sci Technol. 2003;13(5):459-475.

28. Thompson GD, Dutton R, Sparks TC. Spinosad - a case study: an example from a natural products discovery programme. Pest Manag Sci. 2000;56(8):696-702.

29. Li Z-Z, Xu S-A, Wen L-X, et al. Controlled release of avermectin from porous hollow silica nanoparticles: influence of shell thickness on loading efficiency, UV-shielding property and release. J Control Release. 2006;111(1-2):81-88.

30. YiY, Xu S, Sun H, et al. Gelation of photocrosslinkable carboxymethyl chitosan and its application in controlled release of pesticide. Carbohydr Polym. 2011;86(2):1007-1013.

31. Margni M, Rossier D, Crettaz P, Jolliet O. Life cycle impact assessment of pesticides on human health and ecosystems. Agric Ecosyst Environ. 2002;93(1-3):379-392.

32. Peppas NA, Langer R. New challenges in biomaterials. Science. 1994;263(5154):1715-1720.

33. Elango G, Rahuman AA, Kamaraj C, Bagavan A, Zahir AA. Adult emergence inhibition and adulticidal activity of leaf crude extracts against Japanese encephalitis vector, Culex tritaeniorhynchus. J King Saud Univ Sci. 2012;24(1):73-80.

34. Durán N, Islan GA, Durán M, Castrod GR. Nanobiotechnology solutions against Aedes aegypti. J Braz Chem Soc. 2016;27(7):1139-1149.

35. Yan H, Feng Y, Hu W, et al. Preparation and evaluation of alginatechitosan-bentonite based beads for the delivery of pesticides in controlled-release formulation. Asian J Chem. 2013;25(17):9936-9940.

36. Nnamonu LA, Sha'Ato R, Onyido I. Alginate reinforced chitosan and starch beads in slow release formulation of imazaquin herbicide — preparation and characterization. Mater Sci Appl. 2012;3(8):566-574.

37. Roy A, Singh SK, Bajpai J, Bajpai AK. Controlled pesticide release from biodegradable polymers. Cent Eur J Chem. 2014;12(4):453-469.

38. Benelli G, Canale A, Higuchi A, Murugan K, Pavela R, Nicoletti M The recent outbreaks of Zika virus: mosquito control faces a further challenge. Asian Pac J Trop Dis. 2016;6(4):253-258.

39 Agnihotri SA, Aminabhavi TM. Controlled release of clozapine through chitosan microparticles prepared by a novel method. J Control Release. 2004;96(2):245-259.

40. Hou W, Miyazaki S, Takada M, Komai T. Sustained release of indomethacin from chitosan granules. Chem Pharm Bull (Tokyo). 1985;33(9):3986-3992.

41. Miyazaki S, Ishii K, Nadai T. The use of chitin and chitosan as drug carriers. Chem Pharm Bull (Tokyo). 1981;29(10):3067-3069.

42. Borzacchiello A, Ambrosio L, Netti PA, et al. Chitosan-based hydrogels: synthesis and characterization. J Mater Sci Mater Med. 2001;12(10-12):861-864.

43. Soppirnath KS, Aminabhavi TM. Water transport and drug release study from cross-linked polyacrylamide grafted guar gum hydrogel microspheres for the controlled release application. Eur J Pharm Biopharm. 2002;53(1):87-98.

44. Connick Jr WJ, Bradow JM, Wells W, Steward KK, Van TK. Preparation and evaluation of controlled-release formulations of 2,6-dichlorobenzonitrile. J Agric Food Chem. 1984;32(5):1199-1205.

45. Zhang Z, Luo Y, Chen J, et al. Formation of linear supramolecular polymers that is driven by $\mathrm{C}-\mathrm{H} \cdots \pi$ interactions in solution and in the solid state. Angew Chem Int Ed Engl. 2011;123(6):1433-1437.
46. Fernández-Pérez M, Villafranca-Sanchez M, Gonzalez-Pradas E, Martinez-Lopez F, Flores-Cespedes F. Controlled release of carbofuran from an alginate-bentonite formulation: water release kinetics and soil mobility. J Agric Food Chem. 2000;48(3):938-943.

47. Johnson RM, Pepperman AB. Leaching of alachlor from alginateencapsulated controlled-release formulations. Pestic Sci. 1996;48(2): 157-164.

48. Zohuriaan-Mehr MJ, Pourjavadi A. New polysaccharide-g-polyacrylonitrile copolymers: synthesis and thermal characterization. Polym Adv Technol. 2003;14(7):508-516.

49. Kumbar SG, Aminabhavi TM. Preparation and characterization of interpenetrating network beads of poly(vinyl alcohol)-graftedpoly(acrylamide) with sodium alginate and their controlled release characteristics for cypermethrin pesticide. J Appl Polym Sci. 2002;84(3):552-560.

50. Yeom CK, Lee KH. Characterization of sodium alginate membrane crosslinked with glutaraldehyde in pervaporation separation. $\mathrm{J} \mathrm{Appl}$ Polym Sci. 1998;67(2):209-219.

51. El-Bokl MM, Moawad HM. Evaluation of some plant extracts as mosquito larvicides. Ain Ahams Sci Bull. 1996;34:351-362.

52. Finney DJ. Probit Analysis. 3rd ed. Cambridge and New York: Cambridge University Press; 1971.

53. Abbott WS. A method of computing the effectiveness of an insecticide. J Econ Entomol. 1925;18(2):265-267.

54. Badawy MEI, Taktak NEM, Awad OM, Elfiki SA, El-Ela NEA. Larvicidal activity of temephos released from new chitosan/alginate/ gelatin capsules against Culex pipiens. Int J Mosq Res. 2015;2(3): 45-55.

55. Momin RA, Nair MG. Mosquitocidal, nematicidal, and antifungal compounds from Apium graveolens L. seeds. J Agric Food Chem. 2001;49(1):142-145.

56. Paula HCB, de Paula RCM, Bezerral SKF. Swelling and release kinetics of larvicide-containing chitosan/cashew gum beads. J Appl Polym Sci. 2006;102(1):395-400

57. Lowry OH, Rosebrough NJ, Farr AL, Randall RJ. Protein measurement with the Folin phenol reagent. J Biol Chem. 1951;193(1): 265-275.

58. Ellman GL, Courtney KD, Featherstone RM. A new and rapid colorimetric determination of acetylcholinesterase activity. Biochem Pharmacol. 1961;7(2):88-95.

59. Chanda SM, Mortensen SR, Moser VC, Padilla S. Tissue-specific effects of chlorpyrifos on carboxylesterase and cholinesterase activity in adult rats: an in vitro and in vivo comparison. Toxicol Sci. 1997;38(2):148-157.

60. Saint-Denis M, Labrot F, Narbonne JF, Ribera D. Glutathione, glutathione-related enzymes, and catalase activities in the earthworm Eisenia fetida andrei. Arch Environ Contam Toxicol. 1998;35(4):602-614.

61. Abbott WS. A method of computing the effectiveness of an insecticide. J Am Mosq Control Assoc. 1987;3(2):302-303.

62. Murata Y, Maeda T, Miyamoto E, Kawashima S. Preparation of chitosanreinforced alginate gel beads - effects of chitosan on gel matrix erosion. Int J Pharm. 1993;96(1-3):139-145.

63. Shu XZ, Zhu KJ. A novel approach to prepare tripolyphosphate/chitosan complex beads for controlled release drug delivery. Int J Pharm. 2000;201(1):51-58.

64. Wong TW, Chan LW, Kho SB, Sia Heng PW. Design of controlled-release solid dosage forms of alginate and chitosan using microwave. J Control Release. 2002;84(3):99-114.

65. Wan Ngah WS, Kamari A, Koay YJ. Equilibrium and kinetics studies of adsorption of copper (II) on chitosan and chitosan/PVA beads. Int $J$ Biol Macromol. 2004;34(3):155-161.

66. Suave J, Dall'Agnol E, Pezzin A, Meier M, Silva D. Biodegradable microspheres of poly (3-hydroxybutyrate)/poly ( $\varepsilon$-caprolactone) loaded with malathion pesticide: preparation, characterization, and in vitro controlled release testing. J Appl Polym Sci. 2010;117(6):3419-3427.

67. Singh B, Sharma DK, Gupta A. A study towards release dynamics of thiram fungicide from starch-alginate beads to control environmental and health hazards. J Hazard Mater. 2009;161(1):208-216. 
68. Işiklan N. Controlled release of insecticide carbaryl from sodium alginate, sodium alginate/gelatin, and sodium alginate/sodium carboxymethyl cellulose blend beads crosslinked with glutaraldehyde. $J$ Appl Polym Sci. 2006;99(4):1310-1319.

69. Huang B-b, Yang F-m, Zhang X-x, Zhong J-b, Wu Z-j, Wu G. [Study on key process of preparation of spinosad microsphere: II]. Chin J Pestic Sci. 2011;4:013. Chinese.

70. Zhao S-P, Li L-Y, Cao M-J, Xu W-L. pH- and thermo-sensitive semiIPN hydrogels composed of chitosan, $\mathrm{N}$-isopropylacrylamide, and poly (ethylene glycol)-co-poly ( $\varepsilon$-caprolactone) macromer for drug delivery. Polym Bull. 2011;66(8):1075-1087.

71. Efentakis M, Stamoylis K. A study of dimensional, swelling, and gel changes in hydrophilic and hydrophobic polymer mixtures of chitosan and their possible use as carriers for sustained release drug delivery. Adv Polym Technol. 2011;30(2):110-121.

72. Silverstein RM, Webster FX, Kiemle D, Bryce DL. Spectrometric Identification of Organic Compounds. 6th ed. New York: John Wiley \& Sons; 1968.

73. Singha RK, Gangadhar B, Basu H, Manisha V, Naidu GRK, Reddy AVR. Remediation of malathion contaminated soil using zero valent iron nano-particles. Am J Anal Chem. 2012;3:76-82.

74. Mulla MS, Thavara U, Tawatsin A, Chompoosri J. Procedures for the evaluation of field efficacy of slow-release formulations of larvicides against Aedes aegypti in water-storage containers. J Am Mosq Control Assoc. 2004;20(1):64-73.

75. Toma L, Severini F, Di Luca M, Bella A, Romi R. Seasonal patterns of oviposition and egg hatching rate of Aedes albopictus in Rome. J Am Mosq Control Assoc. 2003;19(1):19-22.

76. Bhan S, Mohan L, Srivastava CN. Relative larvicidal potentiality of nano-encapsulated Temephos and Imidacloprid against Culex quinquefasciatus. J Asia Pac Entomol. 2014;17(4):787-791.
77. Selvi S, Edah MA, Nazni WA, Lee HL, Azahari AH. Characterization on malathion and permethrin resistance by bioassays and the variation of esterase activity with the life stages of the mosquito Culex quinquefasciatus. Trop Biomed. 2007;24(1):63-75.

78. Zahran HE-DM, Abdelgaleil SAM. Insecticidal and developmental inhibitory properties of monoterpenes on Culex pipiens L.(Diptera: Culicidae). J Asia Pac Entomol. 2011;14(1):46-51.

79. Rawash IA, Gaaboub IA, El-Gayar EM, El-Shazli AY. Standard curves for nuvacron, malathion, sevin, DDT and kelthane tested against the mosquito Culex pipiens L. and the microcrustacean Daphnia magna Straus. Toxicology. 1975;4(2):133-144.

80. Kovendan K, Murugan K, Kumar AN, Vincent S, Hwang J-S. Bioefficacy of larvicidal and pupicidal properties of Carica papaya (Caricaceae) leaf extract and bacterial insecticide, spinosad, against chikungunya vector, Aedes aegypti (Diptera: Culicidae). Parasitol Res. 2012;110(2):669-678.

81. Badawy MEI, Nasr HM, Rabea EI. Toxicity and biochemical changes in the honey bee Apis mellifera exposed to four insecticides under laboratory conditions. Apidologie. 2015;46(2):177-193.

82. Devonshire AL, Moores GD. Different forms of insensitive acetylcholinesterase in insecticide-resistant house flies (Musca domestica). Pestic Biochem Physiol. 1984;21(3):336-340.

83. Pralavorio M, Fournier D. Drosophila acetylcholinesterase: characterization of different mutants resistant to insecticides. Biochem Genet. 1992;30(1-2):77-83.

84. Chen CD, Nazni WA, Lee HL, Seleena B, Sofian-Azirun M. Biochemical detection of temephos resistance in Aedes (Stegomyia) aegypti (Linnaeus) from dengue-endemic areas of Selangor state, Malaysia. Proc ASEAN Congr Trop Med Parasitol. 2008;3:6-20.

85. Vaughan A, Chadee DD, French-Constant R. Biochemical monitoring of organophosphorus and carbamate insecticide resistance in Aedes aegypti mosquitoes from Trinidad. Med Vet Entomol. 1998;12(3):318-321.
Research and Reports in Tropical Medicine

\section{Publish your work in this journal}

Research and Reports in Tropical Medicine is an international, peerreviewed, open access journal publishing original research, case reports, editorials, reviews and commentaries on all areas of tropical medicine, including: Diseases and medicine in tropical regions; Entomology; Epidemiology; Health economics issues; Infectious disease; Laboratory

\section{Dovepress}

science and new technology in tropical medicine; Parasitology; Public health medicine/health care policy in tropical regions; and Microbiology. The manuscript management system is completely online and includes a very quick and fair peer-review system. Visit http://www.dovepress. com/testimonials.php to read real quotes from published authors. 